\section{Effect of a C/EBP gene replacement on mitochondrial biogenesis in fat cells}

\author{
Chih-Hsien Chiu, Wen-Der Lin, \\ Shao-Yong Huang, and Ying-Hue Lee ${ }^{1}$
}

Laboratory of Molecular Pathology, Institute of Molecular Biology, Academia Sinica, Taipei 115, Taiwan

CCAAT/enhancer-binding proteins, C/EBP $\alpha$ and C/EBP $\beta$, are required for fat cell differentiation and maturation. Previous studies showed that replacement of $\mathrm{C} / \mathrm{EBP} \alpha$ with $\mathrm{C} / \mathrm{EBP} \beta$, generating the $\beta / \beta$ alleles in the mouse genome, prevents lipid accumulation in white adipose tissue (WAT). In this study, $\beta / \beta$ mice lived longer and had higher energy expenditure than their control littermates due to increased WAT energy oxidation. The WAT of $\beta / \beta$ mice was enriched with metabolically active, thermogenic mitochondria known for energy burning. The $\beta / \beta$ allele exerted its effect through the elevated expression of the $G$ protein $\alpha$ stimulatory subunit $\left(\mathbf{G} \alpha_{s}\right)$ in WAT. $G \alpha_{s}$, when overexpressed in fat-laden 3T3-L1 cells, stimulated mitochondrial biogenesis similar to that seen in the WAT of $\beta / \beta$ mice, and effectively diminished the stored lipid pool.

Received April 20, 2004; revised version accepted June 17, 2004.

At its simplest level, obesity is a disorder of energy balance, where energy intake exceeds energy expenditure; as a consequence, the excess energy is stored in the form of fat in adipocytes. The primary onset mechanisms are dietary and/or genetic (Kopelman 2000). Of those known genetic factors involved in determining adiposity in animals, many are regulatory and exert their effect directly on adipocyte differentiation and development (Rosen et al. 2000; Flier 2004). These factors include CCAAT/enhancer-binding proteins (C/EBPs), SREBP, and PPAR $\gamma$, whose concerted action during adipogenesis leads to the development of fat-laden mature adipocytes (Rosen et al. 2000).

The C/EBP family consists of five members, of which $\mathrm{C} / \mathrm{EBP} \alpha, \mathrm{C} / \mathrm{EBP} \beta$, and $\mathrm{C} / \mathrm{EBP} \delta$ have a profound impact on fat cell differentiation (Yeh et al. 1995). During adipogenesis, C/EBP family functions in a transcriptional cascade, in which the early and transiently expressed $\mathrm{C} / \mathrm{EBP} \beta$ and C/EBP $\delta$ activate transcription of PPAR $\gamma$. PPAR $\gamma$ is then responsible for the expression of $\mathrm{C} / \mathrm{EBP} \alpha$ (Wu et al. 1996; Rosen et al. 1999). Subsequently, PPAR $\gamma$ and $\mathrm{C} / \mathrm{EBP} \alpha$, together with SREBP, work synergistically to transactivate expression of most or all of the genes encoding for factors, such as fatty-acid synthase and adi-

[Keywords: C/EBP; gene replacement; $\mathrm{G} \alpha_{s}$; WAT adipocyte; mitochondrial biogenesis]

${ }^{1}$ Corresponding author.

E-MAIL yinghue@gate.sinica.edu.tw; FAX 886-2-26517983.

Article published online ahead of print. Article and publication date are at http://www.genesdev.org/cgi/doi/10.1101/gad.1213104. pocyte-specific fatty acid-binding protein aP2, which characterize the fat cell phenotype (Speigelman et al. 1993).

In this study, we used previously manipulated gene knock-in mice, known as $\beta / \beta$ mice, in which the $\mathrm{C} / \mathrm{EBP} \alpha$ gene has been replaced by the $\mathrm{C} / \mathrm{EBP} \beta$ gene (referred here as $\beta / \beta$ allele) to study their function in tissues (Chen et al. 2000$)$. $\beta / \beta$ mice are lean, and despite markedly reduced fat storage in their fat cells, they do not develop hyperlipidemia or fatty liver, commonly found in the forced leaness that typically causes the liver to take up and store fatty acids when their circulating levels are elevated (Moitra et al. 1998; Shimomura et al. 1998; Chen et al. 2000). We monitored closely the physiology and lifespan of the lean $\beta / \beta$ mice and undertook mechanistic studies to understand the effect of $\beta / \beta$ allele in energy metabolism. We found that the $\beta / \beta$ allele caused an increase in mitochondrial biogenesis only in fat cells of white adipose tissues (WAT), and this WAT specifically enhanced mitochondrial biogenesis was possibly elicited by the markedly elevated expression of $G$ protein $\alpha$ stimulatory subunit $\left(\mathrm{G} \alpha_{\mathrm{s}}\right)$.

\section{Results and Discussion}

To better understand the physiology of lean $\beta / \beta$ mice, we monitored their lifespan, energy expenditure, and responses to diet-induced stress. The average longevity of $\beta / \beta$ mice $(28.9 \pm 5.7 \mathrm{mo}$; Fig. $1 \mathrm{~A})$ was 5.2 mo longer than that of their heterozygous littermates $(23.7+3.9 \mathrm{mo}$; Fig. 1A). Although $\beta / \beta$ mice consumed more food (Chen et al. 2000), their locomotor activity was similar to that of their heterozygous littermates (data not shown), but their body temperature $\left(38.9^{\circ} \mathrm{C} \pm 0.3^{\circ} \mathrm{C}\right)$ was $0.3^{\circ} \mathrm{C}-0.5^{\circ} \mathrm{C}$ higher than that of their wild-type littermates $\left(38.5^{\circ} \mathrm{C} \pm 0.2^{\circ} \mathrm{C}\right)$. They also consumed and produced significantly more $\mathrm{O}_{2}$ and $\mathrm{CO}_{2}$, respectively, than their heterozygous littermates at the ages examined (Fig. 1B), indicating that $\beta / \beta$ mice expend more energy than their heterozygous littermates. To examine their response to dietary stress, $\beta / \beta$ mice were fasted or fed a high-fat $(\mathrm{HF})$ diet. Despite losing more of their body weight than their heterozygous littermates during the 48-h fasting period, they recovered it with a speed (Logarithmic trend: $\left.\mathrm{y}=19.362 \mathrm{Ln}(\mathrm{X})+73.819 ; \mathrm{R}^{2}=0.95\right)$ similar to that of their heterozygous littermates (Logarithmic trend: $y=19.572 \operatorname{Ln}(X)+81.572 ; R^{2}=0.97$; Fig. $\left.1 C\right)$. This indicated that the lean state of $\beta / \beta$ mice did not affect their ability to sustain and recover from fasting stress. When fed a high-fat diet (30\% fat), the heterozygous control mice gained $25 \%$ more weight than those fed the standard diet. In contrast, although $\beta / \beta$ mice consumed more HF food (19\% more) than their heterozygous littermates throughout the 6-wk period, they did not gain more weight than those fed the standard diet (Fig. 1D), indicating that the $\beta / \beta$ mice are protected from diet-induced weight gain.

We next introduced the $\beta / \beta$ alleles into $L e p^{o b / o b}$ and $C p e^{f a t / f a t}$ mice. Cpe fat/fat mice do not consume more food than normal mice, but become obese due to an energy expenditure problem, whereas $L e p^{o b / o b}$ mice are obese in part because of an excessive food intake (Zhang et al. 1994; Naggert et al. 1995). $\beta / \beta \times L e p^{o b / o b}$ and $\beta / \beta \times C p e^{f a t / f a t}$ pups, carrying homozygous $\beta / \beta$ alleles, 
A
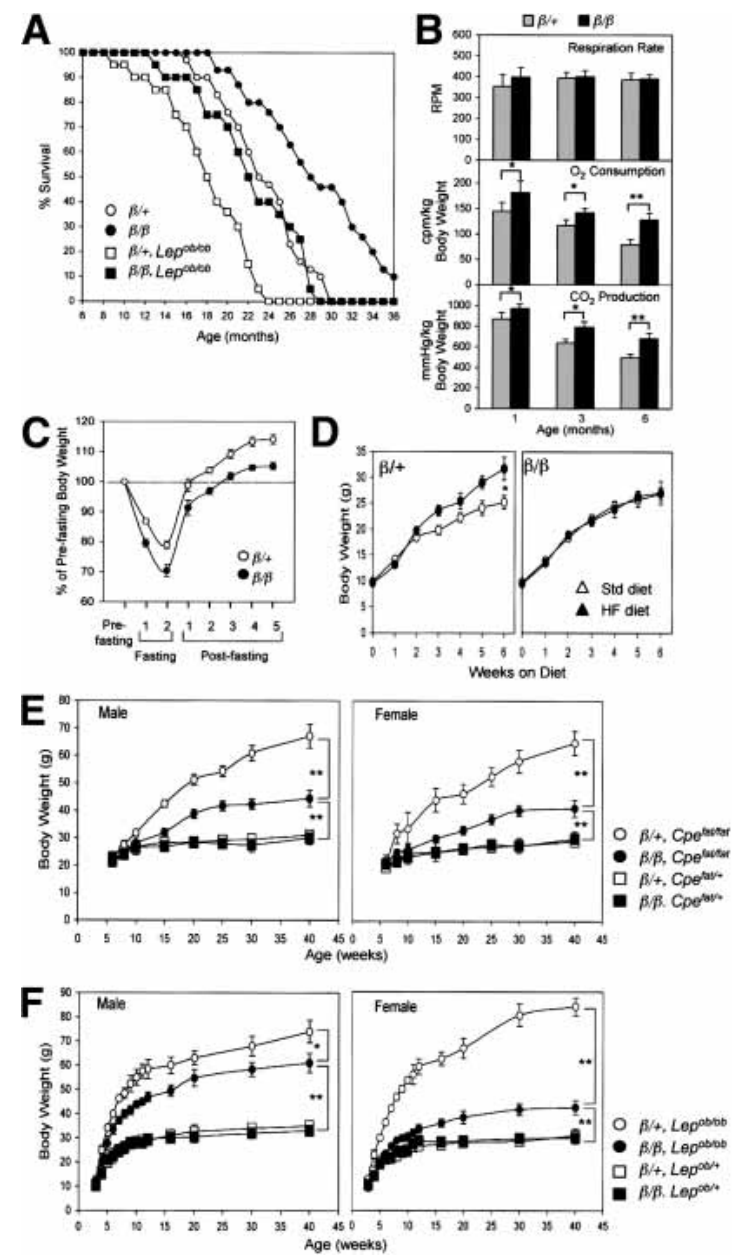

Figure 1. State of health of $\beta / \beta$ mice and the effect of $\beta / \beta$ allele on the monogenic obese mutants $C p e^{f a t / f a t}$ and $L e p^{o b / o b}$ and on weight gain induced by a high-fat diet. $(A)$ Lifespan of $\beta / \beta$ mice. The values depicted are the percentage of surviving mice from the original mice of each group $(n=30-40)$. The respiration parameters $(B)$ and bodyweight recovery after fasting $(C)$ in $\beta / \beta$ mice. Each bar represents the mean \pm S.E.M. $(n=6-8) .\left(^{\star}\right) p<0.05 ;\left(^{\star \star}\right) p<0.01$ between the two groups indicated. The effect of the $\beta / \beta$ allele on weight gain induced by a high-fat diet (HF; $D)$, and on monogenic obese mutants $C p e^{\text {fat/fat }}$ $(E)$ and $L e p^{o b / o b}(F)$. Each bar represents the mean \pm S.E.M. $(n=5-8)$. (Std) standard diet; $\left.\left.\right|^{\star}\right) p<0.05 ;\left(^{\star \star}\right) p<0.01$ between the two groups of mice indicated.

appeared normal prior to weaning, but grew much slower than their respective littermates, Lep ${ }^{o b / o b}$ and Cpe fat/fat (Fig. 1E,F). Although $\beta / \beta \times C p e^{\text {fat } / f a t}$ and $C p e^{\text {fat/fat }}$ mice had the same food intake, at $40 \mathrm{wk}$ of age, the $C p e^{\text {fat /fat }}$ mice of both sexes were $120 \%$ heavier than their heterozygous littermates, but the $\beta / \beta \times C p e^{\text {fat } / \text { at }}$ mice were only $40 \%$ heavier (Fig. 1E). Similarly, weight gain in $\beta / \beta \times L e p^{o b / o b}$ mice was markedly reduced. At $40 \mathrm{wk}$ of age, Lep ${ }^{o b / o b}$ mice of both sexes were $>150 \%$ heavier than their heterozygous littermates, whereas the male and female $\beta / \beta \times$ Lep ${ }^{o b / o b}$ mice were only $85 \%$ and $45 \%$ heavier, respectively (Fig. 1F). The amount of food eaten did not differ significantly between male $L e p^{o b / o b}$ and $\beta / \beta \times L e p^{o b / o b}$ mice, but female $\beta / \beta \times L e p^{o b / o b}$ mice consumed $50 \%$ less than female Lep ob ob mice. $\beta / \beta \times$ $L e p^{o b / o b}$ mice, despite exhibiting a lower weight gain, showed a hyperinsulinemia, hyperglycemia, and infertil- ity similar to their $L e p^{o b / o b}$ littermates (data not shown), indicating that the $\beta / \beta$ alleles were unable to improve these leptin-deficient physiological states. Nevertheless, $\beta / \beta \times L e p^{o b / o b}$ mice had increased longevity $(23.1 \pm 4.7$ mo) compared with their $L e p^{o b / o b}$ littermates $(18 \pm 4 \mathrm{mo}$; Fig. 1A). Taken together, homozygous $\beta / \beta$ alleles efficiently prevented marked weight gain, but not the other abnormalities associated with the loss of Lep or Cpe gene function.

To assess the energy expenditure profile of $\beta / \beta$ mice, we assayed various $\beta / \beta$ mouse tissues for the expression of genes involved in mitochondrial oxidative respiration and their enzymatic activity (Scheffler 1999). The expression of genes encoding cytochrome $b$ and NADH dehydrogenase and the activity of cytochrome $c$ oxidase (COX) in WAT of $\beta / \beta$ mice were markedly higher than that of their heterozygous littermates (Fig. 2A,C). WAT is designed for fat storage, whereas brown adipose tissue (BAT) is used for fat combustion. Surprisingly, WAT was the only tissue to possess elevated COX activities in $\beta / \beta$ mice (Fig. 2; data not shown), whereas there was no difference in COX activity in the muscle and BAT, the two major sites for energy burning and thermogenesis (Lowell et al. 1993; Flier 1995), of $\beta / \beta$ mice and their heterozygous littermates. Structurally, the mitochondrial content of WAT adipocytes is low, whereas BAT adipocytes are enriched with mitochondria (Nicholls and Loche 1984; Loncar et al. 1988). The high level of mitochondrial biogenesis in BAT is indicative of an extremely high metabolism. The increased energy oxidation in the WAT of $\beta / \beta$ mice as compared with heterozygous mice is likely to have resulted from an increase in metabolically active mitochondria. Electron microscopy showed that the mitochondrial volume was dramatically increased in the epididymal WAT adipocytes of $\beta / \beta$ mice as compared with that of their heterozygous littermates (Fig. 2D). The mitochondria in the WAT adipocytes of $\beta / \beta$ mice are full of straight or slightly wavy cirstae that transverse the width of the mitochondria (Fig. 2D, top, left windows), thereby increasing their surface area-a typical characteristic of metabolically active mitochondria (Loncar et al. 1988). The BAT adipocytes of $\beta / \beta$ mice in comparison to heterozygous mice, however, did not possess this increase in mitochondria or changes in mitochondrial activity (Fig. 2D). BAT utilizes UCPs to uncouple oxidative phosphorylation in the mitochondrial Electron Transfer Chain reaction, thereby reducing ATP production, and thus efficiently dissipating energy as heat (Nicholls and Loche 1984). UCPs are expressed in a tissue-specific manner; UCP1 is BAT specific, UCP2 is expressed in most tissues, whereas UCP3 is found in BAT and skeleton muscle (Jacobsson et al. 1985; Boss et al. 1997; Fleury et al. 1997). Interestingly, UCP1 mRNA levels were markedly elevated in WAT but not in other tissues of $\beta / \beta$ mice (Fig. $2 B$ ), indicating that the WAT of $\beta / \beta$ mice might have dissipated energy as heat in a similar manner to that of BAT. This would explain the higher body temperatures seen in $\beta / \beta$ mice.

To understand the molecular mechanism by which $\beta / \beta$ allele confers BAT-like characteristics to WAT of $\beta / \beta$ mice, we used cDNA subtraction to analyze the WAT gene expression profile (Diatchenko et al. 1996). We found that the levels of mRNAs for the growth hormone receptor (GHR), both full-length (GHR-L) and spliced (GHR-S), and $\beta_{3}$ adrenergic receptor (AR), were significantly reduced in WAT, whereas the mRNA levels 

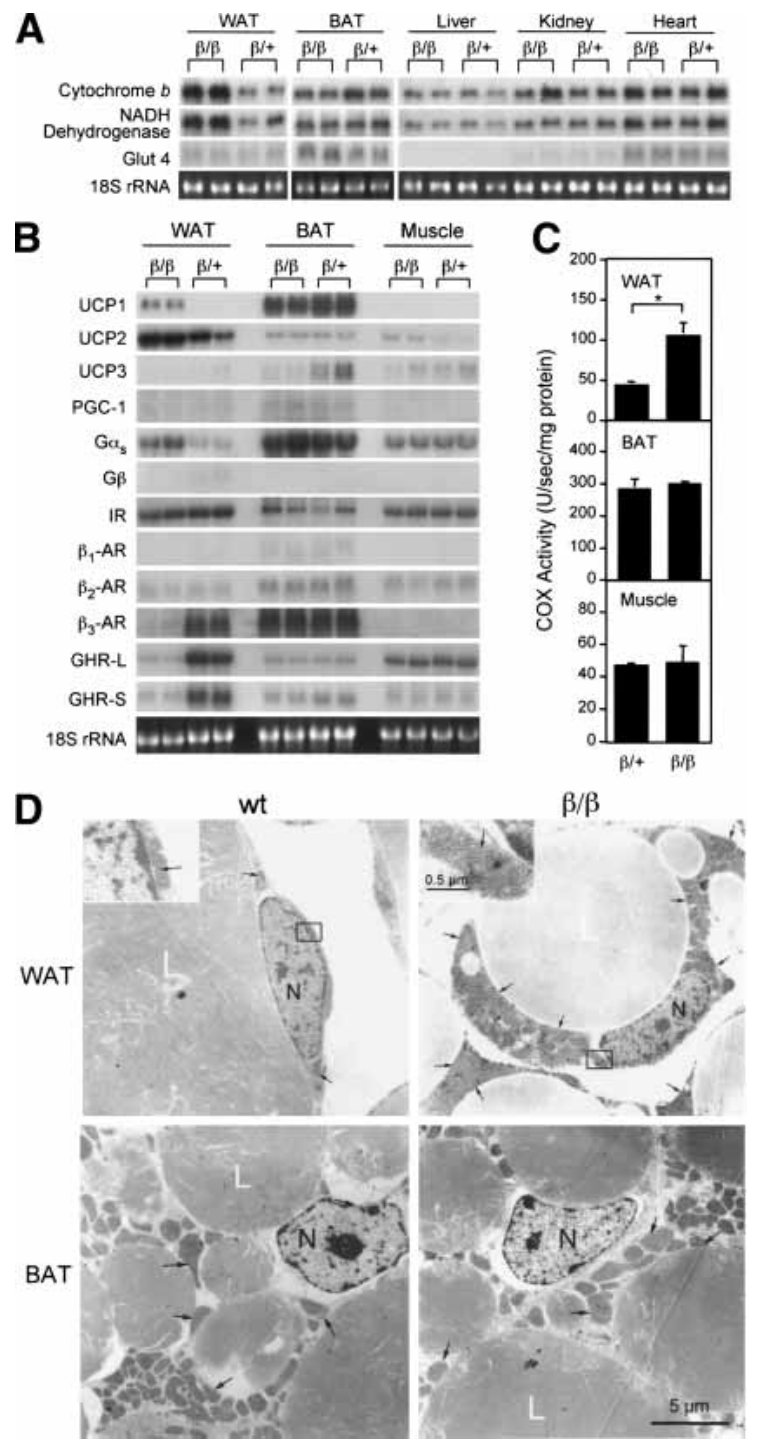

Figure 2. Mitochondria-enriched WAT and increased expression of genes encoding factors involved in energy oxidation in WAT of $\beta / \beta$ mice. Northern blot analyses of enzyme genes involved in mitochondrial Electron Transfer Chain $(A)$ and regulators $(B)$ in tissues of $\beta / \beta$ mice. Each lane contains $10 \mu \mathrm{g}$ RNA from an individual animal. (C) Cytochrome c oxidase (COX) activity of tissue extracts of $\beta / \beta$ mice. Each bar represents the mean \pm S.E.M. $(n=5) .\left(^{\star}\right) p<0.05$ between the two groups of mice indicated. $(D)$ Electron micrograph of adipocytes from epididylmal (WAT) and brown adipose tissues (BAT) of 4 -week-old $\beta / \beta$ mice. Top windows show a higher magnification of the rectangle-enclosed area on the WAT micrograph. (L) lipid droplets; (N) nucleus. Black arrows indicate representative mitochondria.

for insulin receptor (IR) remained unaffected (Fig. 2B). This indicated that growth hormone and adrenergic factor signal transductions might be compromised in WAT of $\beta / \beta$ mice. Interestingly, the expression of $G \alpha_{s}$, which couples with growth factor receptors such as $\beta$-AR (Neves et al. 2002) to mediate their activation, was markedly increased in WAT of $\beta / \beta$ mice (Fig. $2 B$ ). Also increased were the cellular levels of cAMP, an intracellular signal transducer for the activated $\mathrm{G} \alpha_{\mathrm{s}}$, which was $65 \%$ higher in the WAT of $\beta / \beta$ mice $(18.1 \pm 2.3$ pmole/ mg protein) than that of $\beta /+$ mice $(11.7 \pm 1.4$ pmole $/ \mathrm{mg}$ protein).
Markedly increased mitochondrial content, elevated oxidative activity, and altered gene expression were observed only in the WAT of $\beta / \beta$ mice. To determine whether these changes were associated with the maturation status of adipocytes, we isolated preadipocytes directly from epididymal fat pads of the respective mice, and hormonally induced them to become lipid-rich cells that were subsequently sorted and collected for further analyses using flow cytometry (Lee et al. 2004). Small lipid droplets were detected microscopically $2 \mathrm{~d}$ after adipogenic induction in both $\beta /+$ and $\beta / \beta$ cells, indicating that their speed of adipogenic conversion did not differ significantly (Fig. 3A). However, similar to the WAT of $\beta / \beta$ mice, lipid accumulation in $\beta / \beta$ cells afterward appeared slower than in $\beta /+$ cells, as measured by the size and number of lipid droplets (Fig. 3A). Oxygen consumption and $\mathrm{G} \alpha_{\mathrm{s}}$ protein levels were initially similar between $\beta /+$ and $\beta / \beta$ cells, but were significantly higher in the lipid-rich $\beta / \beta$ cells afterward (Fig. 3B,C). These results indicated that the elevated levels of $\mathrm{G} \alpha$ s and mitochondrial biogenesis found in the WAT of $\beta / \beta$ mice might have occured after the conversion of preadipocytes to lipid-rich cells. The levels of cellular cAMP were also elevated in the lipid-rich $\beta / \beta$ cells (Fig. $3 \mathrm{C}$ ), which could be associated with the effect of the increased expression of $\mathrm{G} \alpha_{\mathrm{s}}$ on adenylyl cyclase (AC) catalyzing the formation of cAMP (Gilman 1987). Whereas the IR-, $\beta$-AR-, and GHR-mediated regulatory networks all play an important role in regulating lipid storage in fat cells by affecting their lipolysis and/or lipogenesis, the $\mathrm{G} \alpha_{\mathrm{s}}$-coupled $\beta$-AR pathway has well-documented thermogenic effects through the action of UCP1 (Nam and Lobie 2000; Saltiel and Kahn 2001; Arch 2002; Lowell and Bachman 2003). To determine whether the elevated levels of $\mathrm{G} \alpha_{\mathrm{s}}$ and its associated cAMP are involved in preventing lipid accumulation in $\beta / \beta$ cells, we used an inhibitor of AC, 9-cyclopentyl adenine (9-CP-Ade), to suppress the AC regulatory pathway in the lipid-rich $\beta / \beta$ cells. In the presence of 9 -CP-Ade, $\beta / \beta$ cells were able to increase their lipid storage to a degree comparable to that seen in $\beta /+$ cells, as judged by the size and number of lipid droplets formed inside cells (data not shown). This indicated that the elevated expression of $\mathrm{G} \alpha_{\mathrm{s}}$ and its associated regulatory network were involved in suppressing lipid accumulation in $\beta / \beta$ cells.

We next studied the direct effect of $\mathrm{G} \alpha_{\mathrm{s}}$ on lipid-rich cells. Various factors, including $\mathrm{G} \alpha_{\mathrm{s}}$, were delivered into lipid-rich 3T3-L1 cells via a recombinant adenoviral vector (Ad) carrying a GFP expression cassette, allowing infected cells to be identified (He et al. 1998). The infected lipid-rich 3T3-L1 cells were separated from noninfected cells in the same culture using flow cytometry and analyzed with their electron micrography, $\mathrm{O}_{2}$ consumption, and lipid accumulation. The Ad.G $\alpha_{\mathrm{s}}$-infected cells showed higher $\mathrm{O}_{2}$ consumption than uninfected cells (Fig. 4A). In contrast, cells infected with Ad.G $\alpha_{\mathrm{i} 2}$ had lower $\mathrm{O}_{2}$ consumption when compared with uninfected cells, whereas cells infected with Ad carrying only GFP (Ad.Track), PGC-1, GHR-S, mt-TOM20 (translocase of mitochondrial outer membrane, subunit 20), or a truncated form of $\mathrm{G} \alpha_{\mathrm{s}}$ lacking the $\mathrm{N}$-terminal 36 amino acid residues required for membrane targeting and direct contact with G $\beta \gamma$-dimer (Evanko et al. 2000; indicated as tr- $\left.\mathrm{G} \alpha_{\mathrm{s}}\right)$ did not exhibit any change in $\mathrm{O}_{2}$ consumption (Fig. 4A). When examined by electron microscopy, only the cells infected with Ad.G $\alpha_{\mathrm{s}}$ contained enlarged mito- 
chondria full of cristae similar to those seen in the WAT of $\beta / \beta$ mice, (Fig. 4B). Furthermore, upon light microscopic analysis of cellular lipid accumulation, cells infected with Ad.G $\alpha_{s}$ were found to lose their cellular lipid droplets by graduate shrinkage, whereas uninfected cells and those infected with Ad carrying other factors contained lipid droplets that were progressively enlarged and later merged together (Fig. 4C). Taken together, overexpression of $\mathrm{G} \alpha_{\mathrm{s}}$, without addition of a $\beta$-AR agonist, effectively increased mitochondrial volume and $\mathrm{O}_{2}$ consumption, and subsequently reduced lipid accumulation in lipid-rich cells. This suggests that $\mathrm{G} \alpha_{\mathrm{s}}$ might play an active role, in addition to mediating the effect of $\beta$-AR activation, in programming the lipid-rich cells to be efficient in energy oxidation. Moreover, the truncated form of $\mathrm{G} \alpha_{\mathrm{s}}$ did not elicit the same effect as that of fulllength $\mathrm{G} \alpha_{\mathrm{s}}$, suggesting that the interaction with $\mathrm{G} \beta \gamma$ dimer is needed for mitochondrial biogenesis.

The GTPase cycle between G $\beta \gamma$-dimer and G $\alpha$ subunit in $G$ protein-coupled receptor signaling is well established (Gilman 1987; Neves et al. 2002). However, a number of effectors have been shown to be regulated by G $\beta \gamma$-dimer via direct protein interaction. These effectors include several AC isoforms, voltage-gated $\mathrm{Ca}^{2+}$ channels, and muscarinic $\mathrm{K}^{+}$channels (Gautam et al. 1998). For example, G $\beta \gamma$-dimer is a stimulator of Type II and Type IV AC isoforms, but an inhibitor of Type I AC

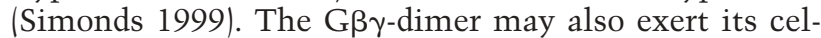
lular effect indirectly by interaction with other proteins, such as calmodulin and mitogen-activated protein kinase (Schwindinger and Robishaw 2001). In the WAT fat cells of $\beta / \beta$ mice, it is unlikely that the effect of $\mathrm{G} \alpha_{\mathrm{s}}$ was in the main associated with the activation of $\beta$-ARs, because $\beta$-AR expression was markedly reduced in the WAT of $\beta / \beta$ mice, possibly due to the lack of $\mathrm{C} / \mathrm{EBP} \alpha$ (Dixon et al. 2001). One possibility is that the elevated levels of $\mathrm{G} \alpha_{\mathrm{s}}$ effectively compete with other $\mathrm{G} \alpha$ subunits for the free form of G $\beta \gamma$-dimer, and subsequently prevent the $\mathrm{G} \beta \gamma$-dimer and/or activation of other $\mathrm{G} \alpha$ subunits
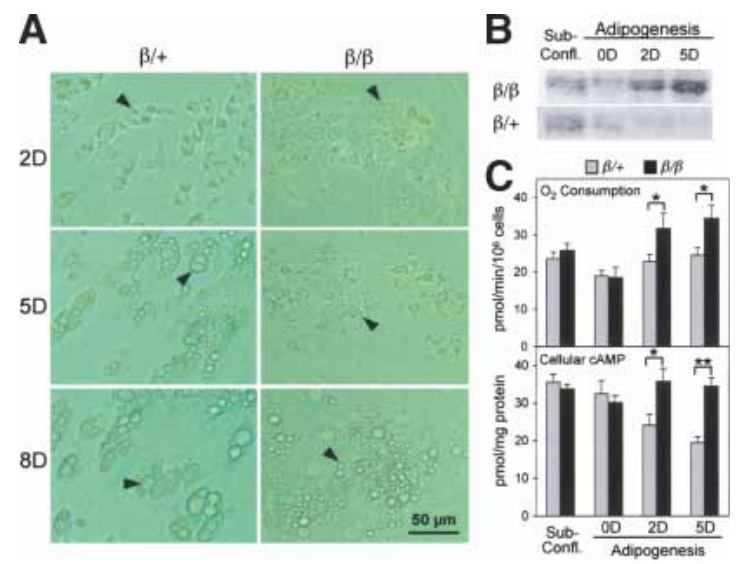

Figure 3. The increased expression of $\mathrm{G} \alpha_{\mathrm{s}}$ protein during adipogenesis of cells derived from WAT of $\beta / \beta$ mice. $(A)$ Light micrograph of cells isolated from epididylmal fat pads of $\beta / \beta$ mice after adipogenic induction. The numbers on the left of the micrograph indicate the days after adipogenic induction. Black arrows indicate representative lipid droplets. Cellular $\mathrm{G} \alpha_{\mathrm{s}}$ protein $(B)$ and oxygen consumption and camp levels $(C)$ of lipid-rich cells after adipogenic induction of the cells isolated from epididylmal fat pads of $\beta / \beta$ mice. Each bar represents the mean \pm S.E.M. $(n=4) .\left(^{\star}\right) p<0.05 ;\left(^{* \star}\right) p<0.01$ between the two groups of mice indicated.
A
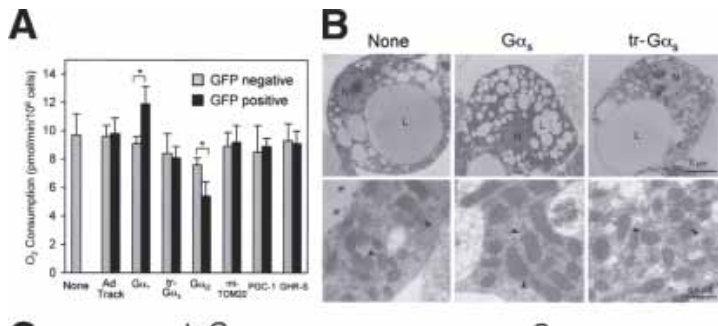

C

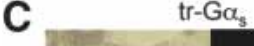

C $\mathrm{tr}-\mathrm{G \alpha}_{\mathrm{s}}$

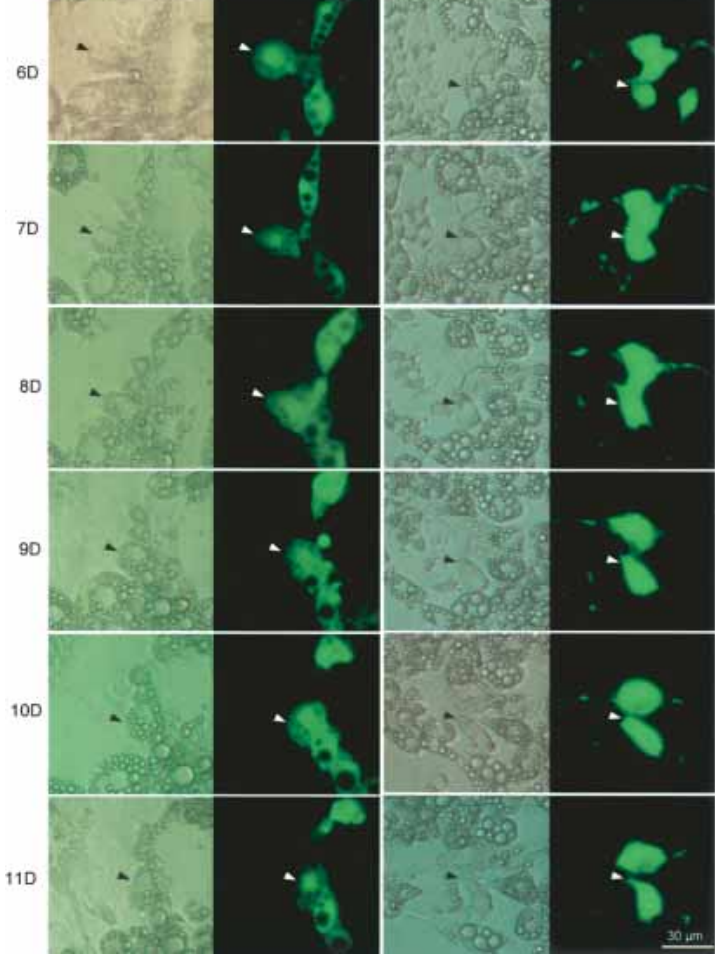

Figure 4. Effects of $\mathrm{G} \alpha_{\mathrm{s}}$ on mitochondrial biogenesis and oxygen consumption in lipid-rich 3T3-L1 cells. (A) Oxygen consumption of lipid-rich 3T3-L1 cells infected with adenoviral vectors expressing the various factors indicated. Each bar represents the mean \pm S.E.M. $(n=4) .\left(^{\star}\right) p<0.05$ between the two groups of mice indicated. $(B)$ Electron micrograph of lipid-rich 3T3-L1 cells infected with adenoviral vectors expressing $\mathrm{G} \alpha_{\mathrm{s}}$ protein. (Right) Higher magnifications of the rectangle-enclosed areas shown at left. (L) lipid droplets; (N) nucleus. Black arrowheads show representative mitochondria. (c) Light micrograph of lipid-rich 3T3-L1 cells infected with adenoviral vectors expressing $G \alpha_{s}$ proteins. Each micrograph shows both light (left) and dark (right, fluorescent) fields in parallel. Black and white arrowheads point to the same cell shown in light and dark fields, respectively. The numbers on the left of the micrograph indicate the number of days after adipogenic induction.

from exerting their cellular effects that may include inhibiting AC activity.

Adipocytes express all three subtypes of $\beta$-AR $(\beta 1, \beta 2$, and $\beta 3$ ), of which each is coupled to the $\mathrm{G} \alpha_{\mathrm{s}}-\mathrm{cAMP}$ pathway. Thus, in adipocytes, especially of BAT, $\mathrm{G} \alpha_{\mathrm{s}}$ has had its role in mediating signaling from the $\beta$-AR activation to elicit lipolysis and thermogenesis well documented (Collins and Surwit 2001; Kelly and Scarpulla 2004). An inhibitory role of $\mathrm{G} \alpha_{\mathrm{s}}$ in adipogenesis of 3T3-L1 cells has been suggested on the basis of the observations that $\mathrm{G} \alpha_{\mathrm{s}}$ expression declines markedly within $24 \mathrm{~h}$ of adipogenic induction, and that antisense $\mathrm{G} \alpha_{\mathrm{s}}$ oligodeoxynucleotides accelerate adipocyte differentiation (Wang et al. 1992). In 
postdifferentiation, however, the regulatory role of $\mathrm{G} \alpha_{\mathrm{s}}$ in adipocyte constitution is not yet defined. Interestingly, C/EBP gene replacement increased and maintained the $\mathrm{G} \alpha_{\mathrm{s}}$ expression specifically at the state of postadipogenic induction when the preadipocytes isolated from WAT of $\beta / \beta$ mice were adipogenically induced. This was corroborated by the WAT-specific increase in $G \alpha_{s}$ expression in $\beta / \beta$ mice. The increases in mitochondrial biogenesis and metabolic activity in lipidrich 3T3-L1 cells after overexpression of $\mathrm{G}_{\mathrm{s}}$ at the postadipogenic induction stage further suggests an active role of $\mathrm{G} \alpha_{\mathrm{s}}$ in defining adipocyte composition during adipocyte differentiation.

In conclusion, this study indicates that the $\beta / \beta$ allele changes the metabolic state of WAT adipocytes from energy storage to energy dissipation, possibly via an increased expression of $\mathrm{G} \alpha_{\mathrm{s}}$. The increase in energy oxidation alone in fat cells appears to be able to reverse both genetic and dietary obesities. Regardless of the cause of obesity, all forms of obesity lead to an accumulation of massive quantities of fat in WAT. Thus, increasing the oxidative activity of WAT might be an effective treatment for obesity. Moreover, as overexpression alone of $\mathrm{G} \alpha_{\mathrm{s}}$ effectively increased mitochondrial biogenesis and prevented fat accumulation in lipid-rich cells, $\mathrm{G} \alpha_{\mathrm{s}}$ might play an active role in programming the lipid-rich cells to be as efficient energy oxidizers as the adipocytes of BAT in which $\mathrm{G} \alpha_{\mathrm{s}}$ is highly expressed.

\section{Materials and methods}

Mice

$C p e^{\mathrm{fat} /+}$ and $L e p^{\mathrm{ob} /+}$ heterozygous mice were obtained from the Jackson Laboratory and bred with $C / e b p \alpha^{\beta / \beta}$ mice /Chen et al. 2000; here referred to as $\beta / \beta$ mice, homozygous for a C/EBP $\beta$ gene knock-in at the $C / e b p \alpha$ locus; $\beta /+$ mice carry one $C / \operatorname{ebp} \beta$ allele at the $C / e b p \alpha$ locus; both mice are wild type at the $C / \operatorname{ebp} \beta$ locus) to generate the respective heterozygous double-mutant mice. These double-mutant heterozygous mice were then interbred to obtain homozygous double-mutant mice, $\beta / \beta \times C p e^{f a t} /$ fat and $\beta / \beta \times L e p^{o b / o b}$, respectively.

High-fat diet experiments

Mice were kept in a sterile microisolator and were observed closely throughout the experiment. To measure the effect of HF diet, six mice of each sex from both $\beta /+$ and $\beta / \beta$ genotypes were placed separately in a microisolator $2.5 \mathrm{wk}$ after birth. Fresh food of standard (4\% fat) or high fat $(30 \%$ fat, LabDiet) was provided daily, and the amount of food consumed was recorded daily. To monitor growth rates, the body weight of mice was measured twice a week.

COX activity assay and cAMP measurement

The COX activity assay was used to assess mitochondrial respiratory activity (Cooperstein and Lazarow 1951). Frozen tissues were homogenized in $10 \mathrm{vol}$ of ice-cold $30 \mathrm{mM}$ phosphate buffer (pH 7.4). A total of $5-20 \mu \mathrm{L}$ of tissue homogenate were then added to $0.5 \mathrm{~mL}$ of reduced cytochrome $c$ solution. The reactions were measured at $550 \mathrm{~nm}$ in a spectrometer, with readings taken every $30 \mathrm{sec}$. Cellular cAMP contents were measured by a cAMP EIA kit (Biomedical Technologies).

Mouse respiration parameters

The respiration rate, $\mathrm{O}_{2}$ consumption, and $\mathrm{CO}_{2}$ production of individual mice, conscious but restrained, were measured using a respiration system coupled with $\mathrm{O}_{2} / \mathrm{CO}_{2}$ sensors (Kent Scientific, Inc). Each mouse was measured in the system at room temperature for $3 \mathrm{~min}$, and twice a day for 3 consecutive days. The final value for each mouse was the average of six measurements.

Preadipocyte isolation and culture

Mouse preadipocytes were isolated from male epidedylmal fat pads and cultured accordingly (Zuk et al. 2001). Similar to 3T3-L1 cells, adipogen- esis was induced by adding insulin, 3-isobutyl-1-methyl-xanthine (IBMX) and dexamethasone to 2-d postconfluent cells (designated Day 0) at final concentrations of $10 \mu \mathrm{g} / \mathrm{mL}, 0.5 \mathrm{mM}$, and $1 \mu \mathrm{M}$, respectively for $2 \mathrm{~d}$ (Sadowski 1992). In addition, $1 \mu \mathrm{M}$ of BRL49653C (rosiglitazone, Smithkline Beecham) was included in the induction medium. Cells were then maintained in culture medium containing $2 \mu \mathrm{g} / \mathrm{mL}$ of insulin until needed.

\section{Flow cytometry and cell sorting}

Adipogenically induced cells were analyzed and sorted in a flow cytofluorometer (FACStar Plus, Becton Dickinson) using FACS (fluorescenceactivated cell sorter) technology (Lee et al. 2004). Cells were dissociated with trypsin, washed twice with PBS, resuspended in cold PBS, and kept on ice before flow cytometric analysis. After sorting, the collected fatladen cells were returned to culture medium and incubated at $37^{\circ} \mathrm{C}$ for at least $12 \mathrm{~h}$ before further analyses.

\section{Recombinant adenovirus generation and infection}

Recombinant viral vectors carrying cDNA encoding the indicated factors were made using the Ad Easy system (Quatum Biol. Inc). The plasmid pAdTrack CMV (He et al. 1998) containing a GFP marker gene and a CMV promoter for expression of the desired factor was used as the transfer vector for viral DNA homologous recombination in bacteria. After homologous recombination, adenoviral genomic DNA having a cDNA correctly integrated was transfected into 293 cells for virus production according to manufacturer's protocol. To infect the adipogenically induced 3T3-L1 cells, recombinant adenoviruses were added directly to the culture medium at the dosage of 50 m.o.i., and incubated for $24 \mathrm{~h}$.

Cell $\mathrm{O}_{2}$ consumption

Immediately prior to measurement, cells were harvested by trypsinization, washed twice in PBS, and resuspended in $0.2 \mathrm{~mL}$ of PBS. Cells were then added to an Oxytherm oxygen electrode (HansaTech) pre-equilibrated and stabilized in $0.5 \mathrm{~mL}$ of oxygen buffer with air at $37^{\circ} \mathrm{C}$. Oxygen consumption was monitored for $10 \mathrm{~min}$, and the value was calculated according to the manufacturer's instruction. The electrode buffer contained 0.3 M mannitol, $10 \mathrm{mM} \mathrm{KCl,} 5 \mathrm{mM} \mathrm{MgCl}$, $10 \mathrm{mM} \mathrm{KH}_{2} \mathrm{PO}_{4}$, and $1 \mathrm{mg} / \mathrm{mL}$ BSA (pH 7.4).

\section{Acknowledgments}

We thank Dimitry Spitkovsky and Rudolf Wiesner for invaluable help with the generation of recombinant adenoviral vectors. This work was supported in part by the NSC grant 92-2311-B001-042 and the Alexander von Humboldt Foundation.

The publication costs of this article were defrayed in part by payment of page charges. This article must therefore be hereby marked "advertisement" in accordance with 18 USC section 1734 solely to indicate this fact.

\section{References}

Arch, J.R.S. 2002. $\beta 3$-adrenoceptor agonists: Potential, pitfalls and progress. Euro. J. Pharm. 440: 99-107.

Boss, O., Samec, S., Paoloni-Giacobino, A., Rossier, C., Dulloo, A., Seydoux, J., Muzzin, P., and Giacobino, J.P. 1997. Uncoupling protein-3: A new member of the mitochondrial carrier family with tissue-specific expression. FEBS Lett. 408: 39-42.

Chen, S.S., Chen, J.F., Johnson, P.F., Muppala, V., and Lee, Y.H. 2000 $\mathrm{C} / \mathrm{EBP} \beta$, when expressed from the C/ebp $\alpha$ gene locus, can functionally replace $\mathrm{C} / \mathrm{EBP} \alpha$ in liver but not in adipose tissue. Mol. Cell Biol. 20: $7292-7299$.

Collins, S. and Surwit, R.S. 2001. The $\beta$-adrenergic receptors and the control of adipose tissue metabolism and thermogenesis. Recent Prog. Horm. Res. 56: 309-328.

Cooperstein, S.J. and Lazarow, A. 1951. A microspectrophotometric method for the determination of cytochrome oxidase. J. Biol. Chem. 189: 665-670.

Diatchenko, L., Lau, Y.F.C., Campbell, A.P., Chenchik, A., Moqadam, F., Huang, B., Lukyanov, S., Lukyanov, K., Gurskaya, N., Sverdlov, E.D., et al. 1996. Suppression subtractive hybridization: A method for generating differentially regulated or tissue-specific cDNA probes and 
libraries. Proc. Nat1. Acad. Sci. 93: 6025-6030.

Dixon, T.M., Daniel, K.W., Farmer, S.R., and Collins, S. 2001. CCAAT/ enhancer-binding protein is required for transcription of the 3-adrenergic receptor gene during adipogenesis. J. Biol. Chem. 276: 722-728.

Evanko, D.S., Thiyagarajan, M.M., and Wedegaertner, P.B. 2000. Interaction with $\mathrm{G} \beta \gamma$ is required from membrane targeting and palmitoylation of $\mathrm{G}_{\mathrm{s}}$ and $\mathrm{G} \alpha_{\mathrm{q}}$. J. Biol. Chem. 275: 1327-1336.

Fleury, C., Neverova, M., Collins, S., Raimbault, S., Champigny, O., levi-Meyrueis, C., Bouillaud, F., Seldin, M.F., Surwit, R.S., Ricquier, D., et al. 1997. Uncoupling protein-2: A novel gene linked to obesity and hyperinsulinemia. Nat. Genet. 15: 269-272.

Flier, J.S. 1995. The adipocyte: Storage depot or node on the energy information superhighway? Cell 80: 15-18.

- 2004. Obesity wars: Molecular progress confronts an expanding epidemic. Cell 116: 337-350.

Gautam, N., Downes, G.B., Yan, K., and Kisselev, O. 1998. The G-protein $\beta \gamma$ complex. Cell Signal 10: 447-455.

Gilman, A.G. 1987. G proteins: Transducers of receptor-generated signals. Annu. Rev. Biochem. 56: 615-649.

He, T.C., Zhou, S., da Costa, L.T., Yu, J., Kinzler K.W., and Vogelsterin, B. 1998. A simplified system for generating recombinant adenoviruses. Proc. Nat1. Acad. Sci. 95: 2509-2514.

Jacobsson, A., Stakler, U., Glotzer, M.A., and Kozak, L.P. 1985. Mitochondrial uncoupling protein from mouse brown fat. Molecular cloning, genetic mapping, and mRNA expression. J. Biol. Chem. 260: 16250-16254.

Kelly, D.P. and Scarpulla, R.C. 2004. Transcriptional regulatory circuits controlling mitochondrial biogenesis and function. Genes \& Dev. 18: 357-368.

Kopelman, P.G. 2000. Obesity as a medical problem. Nature 402: 635643.

Lee, Y.H., Chen, S.Y., Wiesner, R.J., and Huang, Y.F. 2004. Simple flow cytometric method used to assess lipid accumulation in fat cells. J. Lipid Res. 45: 1162-1167.

Loncar, D., Afzelius, B.A., and Cannon, B. 1988. Epididymal white adipose tissue after cold stress in rats. II. Mitochondrial changes. J. U1trastruct. Mol. Struct. Res. 101: 199-209.

Lowell, B.B. and Bachman, E.S. 2003. $\beta$-adreergic receptors, diet-induced thermogenesis, and obesity. J. Biol. Chem. 278: 29385-29388.

Lowell, B.B., S-Susulic, V., Hamann, A., Lawitts, J.A., Himms-Hagen, J., Boyer, B.B., Kozak, L.P., and Flier, J.S. 1993. Development of obesity in transgenic mice after genetic ablation of brown adipose tissue. Nature 366: $740-742$.

Moitra, J.L., Mason, M.M., Olive, M., Krylor, D., Gavrilova, O., MarcusSamuels, B., Feigenbaum, L., Lee, E., Aoyama, T., Eckhaus, M., et al. 1998. Life without white fat: A Transgenic mouse. Genes \& Dev. 12: 3168-3181.

Naggert, J.K., Fricker, L.D., Varlamov, O., Nishina, P.M., Rouille, Y., Steiner, D.F., Carroll, R.J., Paigen, B.J., and Leither, E.H. 1995. Hyperproinsulinaemia in obese fat/fat mice associated with a carboxypeptidase E mutation which reduces enzyme activity. Nat. Genet. 10: $135-142$.

Nam, S.Y. and Lobie, P.E. 2000. The mechanism of effect of growth hormone on preadipocte and adipocyte function. Obesity Rev. 1: $73-$ 86.

Neves, S.R., Ram, R.T., and Lyengar, R. 2002. G protein pathways. Science 296: $1636-1639$.

Nicholls, D.G. and Loche, R.M. 1984. Thermogenic mechanisms in brown fat. Physiol. Rev. 64: 1-64.

Rosen, E.D., Sarraf, P., Troy, A.E., Bradwin, G., Moore, K., Milsotne, D.S., Spiegelman, B.M., and Mortensen, R.M. 1999. PPAR $\gamma$ is required for the differentiation of adipose tissue in vivo and in vitro. Mol. Cell 4: 611-617.

Rosen, E.D., Walkey, C.J., Puigserver, P., and Spiegelman, B.M. 2000. Transcriptional regulation of adipogenesis. Genes \& Dev. 14: $1293-$ 1307.

Sadowski, H.B., Wheeler, T.T., and Young, D.A. 1992. Gene expression during 3T3-L1 adipocyte differentiation. J. Biol. Chem. 266: $4722-$ 4731

Saltiel, A.R. and Kahn, C.R. 2001. Insulin signalling and the regulation of glucose and lipid metabolism. Nature 414: 799-806.

Scheffler, I.E. 1999. Mitochondria, Wiley-Liss, Inc, New York.

Schwindinger, W.F. and Robishaw, J.D. 2001. Heterotrimeric G-protein $\beta \gamma$-dimers in growth and differentiation. Oncogene 20: 1653-1660.

Shimomura, I., Hammer, R.E., Richardson, J.A., Ikemoto, S., Bashmakow, Y., Goldsten, J.L., and Brown, M.S. 1998. Insulin resistance and diabetes mellitus in transgenic mice expressing nuclear SREBP1c in adipose tissue: Model for congential generalized lipodystrophy. Genes \& Dev. 12: 3182-3194.

Simonds, W.F. 1999. G protein regulation of adenylate cyclase. Trends Pharmacol. Sci. 20: 66-73.

Spiegelman, B.M., Choy, L., Hotamisligil, G., Graves, R.A., and Tontonoz, P. 1993. Regulation of adipocyte gene expression in differentiation and syndromes of obesity/diabetes. J. Biol. Chem. 268: 68236826.

Wang, H.-Y., Watkins, D.C., and Malbon, C.C. 1992. Antisense oligodeoxynucleotides to Gs protein $\alpha$-subunit sequence accelerate differentiation of fibroblasts to adipocytes. Nature 358: 334-337.

Wu, Z., Bucher, N.L.R., and Farmer, S.R. 1996. Induction of peroxisome proliferator-activated receptor $\gamma$ during the conversion of $3 \mathrm{~T} 3$ fibroblasts into adipocytes is mediated by $\mathrm{C} / \mathrm{EBP} \beta, \mathrm{C} / \mathrm{EBP} \delta$, and glucocorticoids. Mol. Cell. Biol. 16: 4128-4136.

Yeh, W.C., Cao, Z., Classon, M., and McKnight, S.L. 1995. Cascade regulation of terminal adipocyte differentiation by three members of the C/EBP family of leucine zipper proteins. Genes \& Dev. 9: 168-181.

Zhang, Y., Proenca, R., Maffei, M., Barone, M., Leopold, L., and Friedman, J.M. 1994. Positional cloning of the mouse obese gene and its human homologue. Nature 372: 425-432.

Zuk, P.A., Zhu, M., Mizuno, H., Huang, J., Futrell, J.W., Katz, A.J., Benhaim, P., Lorenz, H.P., and Hedrick, M.H. 2001. Multilineage cells from human adipose tissue: Implications for cell-based therapies. Tissue Engineering 7: 211-228. 


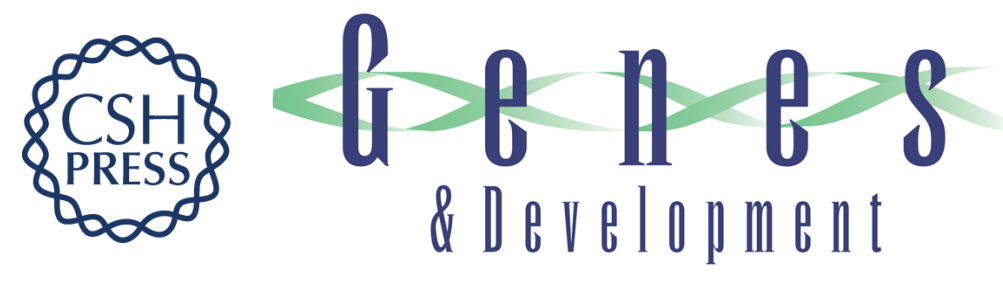

\section{Effect of a C/EBP gene replacement on mitochondrial biogenesis in fat cells}

Chih-Hsien Chiu, Wen-Der Lin, Shao-Yong Huang, et al.

Genes Dev. 2004, 18:

Access the most recent version at doi:10.1101/gad.1213104

References This article cites 37 articles, 17 of which can be accessed free at: http://genesdev.cshlp.org/content/18/16/1970.full.html\#ref-list-1

License

Email Alerting

Receive free email alerts when new articles cite this article - sign up in the box at the top Service right corner of the article or click here.

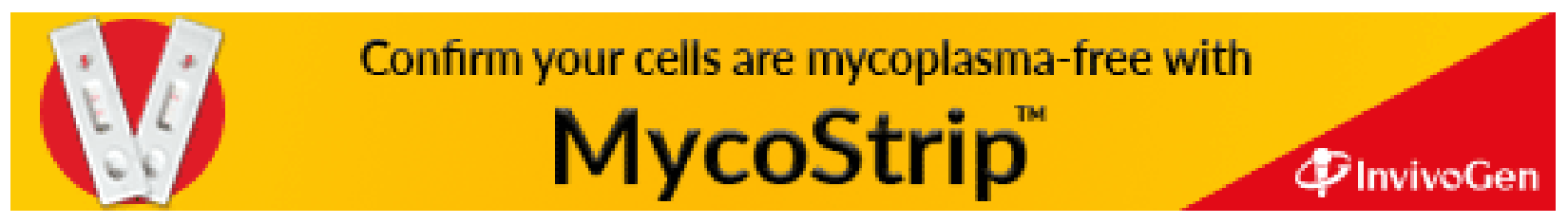

